\title{
水溶液中でのジルコニア固溶体超微結晶の合成と ゾルゲル薄膜への応用
}

\author{
加藤悦朗 · 江 副 正 信 ·大問啓志・近藤正保 \\ (名古屋工業大学材料工学科, 466 名古屋市昭和区御器所町)
}

\section{Synthesis of $\mathrm{ZrO}_{2}$ Solid Solution Ultrafine Crystal by Aqueous Reaction and Application to Preparation of Sol-Gel Film}

\author{
Etsuro KATO, Masanobu EZOE, Keiji DAIMON and Masayasu KONDO \\ (Nagoya Institute of Technology, Gokiso-cho, Showa-ku, Nagoya-shi 466)
}

\begin{abstract}
Highly dispersed tetragonal or cubic zirconia solid solution hydrosols composed of ultrafine particles were prepared by aging coprecipitated hydroxides both of $\mathrm{Zr}-\mathrm{Y}$ and $\mathrm{Zr}$-Ca below $200^{\circ} \mathrm{C}$ for a long duration. In $\mathrm{ZrO} \mathrm{O}_{2}-\mathrm{Y}_{2} \mathrm{O}_{3}$ system, 10-30 mol\% $\mathrm{Y}_{2} \mathrm{O}_{3}$ solid solutions crystallized easily at $97^{\circ} \mathrm{C}$ for 5 days. The solid solution particles with cubic shape of $60-120 \AA$ formed, when 10 mol\% $\mathrm{Y}_{2} \mathrm{O}_{3}$ was added. The solid solutions in the $\mathrm{ZrO}_{2}-\mathrm{CaO}$ system were also obtained at $150^{\circ} \mathrm{C}$ for 3 days. When the coprecipitated hydroxides containing 0-20 mol\% $\mathrm{CaO}$ was washed by saturated $\mathrm{Ca}(\mathrm{OH})_{2}$ solution before aging, the produced solid solution contained 15.3-18.8 mol\% $\mathrm{CaO}$ and they were composed of spherical particles of 30-60A. Translucent thin films of cubic zirconia, both of $\mathrm{ZrO}_{2}-\mathrm{Y}_{2} \mathrm{O}_{3}$ and $\mathrm{ZrO}_{2}-\mathrm{CaO}$ solid solutions, were obtained and they were composed of grains of 1-4 $\mu \mathrm{m}$ after firing at $1350^{\circ} \mathrm{C}$ for $30 \mathrm{~min}$.

[Received August 6, 1987 ; Accepted September 17, 1987]
\end{abstract}

Key-words : Cubic zirconia, $\mathrm{ZrO}_{2}-\mathrm{CaO}, \mathrm{ZrO}_{2}-\mathrm{Y}_{2} \mathrm{O}_{3}$, Ultrafine particle, Sol-gel film

\section{1. 緒言}

ジルコニウム塩の水溶液は $200^{\circ} \mathrm{C}$ 程度までの低温の 加熱によって加水分解し, 水和ジルコニアの超微粒子を 生成する ${ }^{1)-3)}$. この超微粒子は単斜ジルコニアの特徴で ある凝集粒子であることが知られており ${ }^{4)}$, 水溶液中で 直接結晶化するため孤立化した粉末となり焼結性に優れ るので，工業的にもファインセラミックス原料粉末の製 造に応用されている(5),6). しかしながら, 酸素センサ一 などの導電性セラミックスや刃物等の強靶性セラミック スとして知られるすべてのセラミックスは安定化又は部 分安定化ジルコニア，すなわち， $\mathrm{Y}, \mathrm{Ca}$, あるいは $\mathrm{Mg}$ なよ゙の酸化物を含有する正方又は立方型固溶体セラミッ クスであるにもかかわらず，水溶液中で直接固溶体微結 晶を生成してこれを焼結体用に応用する研究は必ずしも 十分に行われていない.

安定化剂のない環境下での水溶液における正方又は立 方型ジルコニアの生成については, 無定形水和 $\mathrm{ZrO}_{2}$ を $\mathrm{H}_{2} \mathrm{O}$ 中 $98 \mathrm{MPa}, 215^{\circ} \sim 245^{\circ} \mathrm{C}, 10 \mathrm{~min}-22 \mathrm{~h}$ の条件下で 正方晶が結晶化すること7), また, $\mathrm{NaOH}$ 溶液中では一 $120^{\circ} \mathrm{C}$ で立方晶微粒子が最初に結晶化し， $300^{\circ} \mathrm{C}$ で突然 単斜晶に変化すること缶られ, 更に $\mathrm{KF}, \mathrm{LiCl}$, $\mathrm{KBr}$ などの水溶液中では $100 \mathrm{MPa}, 200^{\circ} \sim 600^{\circ} \mathrm{C}, 24 \mathrm{~h}$ の処理で正方晶微粒子の生成領域が明らかにされてい る ${ }^{9)}$. 一方, 安定化剂の共存下での結晶生成について,
Burkin ら ${ }^{10)}$ は $\mathrm{Zr}$ と $\mathrm{Y}$ の共沈水酸化物を $190^{\circ} \mathrm{C}, 1 \mathrm{~h}$ オートクレーブ処理して, 粒径 $1500 \pm 35 \AA$ の固溶体微 結晶を初めて水溶液中に結晶化させた。 また, Nishizawa ら ${ }^{11)}$ は無定形水和ジルコニアを $0.01 〜 1.0$ $\mathrm{mol} / \mathrm{l}$ の酢酸 $\mathrm{Ca}$ や酢酸 $\mathrm{Mn}$ (II ) の水溶液中で $50^{\circ}$ $350^{\circ} \mathrm{C}$ に加熱し, 平均粒径 $10 \mathrm{~nm}$ の立方晶ジルコニア固 溶体超微粒子が $270^{\circ} \mathrm{C}$ で結晶化することを見いだし， 条件により $\mathrm{CaO}$ の含有量 $1.5 \sim 11.8 \mathrm{~mol} \%$ となるが, $200^{\circ} \mathrm{C}$ 以下では $\mathrm{Ca}$ の取り込みも結晶化も起こらないこ とを報告している。

本研究では, $\mathrm{Zr}$ と Y 又は $\mathrm{Ca}$ との共沈水酸化物を低 温長時間熟成処理することにより, ジルコニア固溶体微 結晶が $150^{\circ} \mathrm{C}$ 以下で, Y については $100^{\circ} \mathrm{C}$ 以下ですら, 生成することを見いだし，これをゲル化し，ゾルゲルプ ロセスによるセラミックス化を検討した。

\section{2. 実験方法}

\section{1 試料調製}

出発原料として特級試薬オキシ塩化ジルコニウム $\left(\mathrm{ZrOCl}_{2} \cdot 8 \mathrm{H}_{2} \mathrm{O}\right)$ を用いた. $\mathrm{ZrOCl}_{2}$ 水溶液に所定量の 塩化カルシウム $\left(\mathrm{CaCl}_{2} \cdot 2 \mathrm{H}_{2} \mathrm{O}\right)$ 又は塩化イットリウム $\left(\mathrm{YCl}_{3} \cdot 6 \mathrm{H}_{2} \mathrm{O}\right)$ (いずれも特級試薬) を加え, $\mathrm{CaCl}_{2}$ の 場合には $3 \mathrm{~N} \mathrm{KOH}$ 水溶液に, $\mathrm{YCl}_{3}$ のときには, $3 \mathrm{~N}$ $\mathrm{NH}_{4} \mathrm{OH}$ 水溶液に混合して, 共沈水酸化物とした. 以下, 
それぞれ， $\mathrm{Ca}$ 共沈物， $\mathrm{Y}$ 共沈物と記し， $\mathrm{Y}_{2} \mathrm{O}_{3}, \mathrm{CaO}$ に 換算した共沈物への添加量を mol\% で表示する。各共 沈物は $\mathrm{Ca}(\mathrm{OH})_{2}, \mathrm{Y}(\mathrm{OH})_{3}$ 飽和水溶液で洗浄後, 0.3 $\mathrm{mol} / \mathrm{l}$ となるように希釈し， $97^{\circ} \sim 200^{\circ} \mathrm{C}$ で熟成した。 加熱処理温度が $97^{\circ} \mathrm{C}$ の場合には，水溶液をビーカーに 入れ，プラスチックシートで密封し， $100^{\circ} \mathrm{C}$ 以上の場合 は, ステンレス製耐圧容器に收納されたテフロン容器(内 容積 $25 \mathrm{ml}$ ) 中にいれ, 所定温度に保持した恒温槽内に 静置した。加熱処理の後, 既報 ${ }^{22}$ と同様の方法により ゾルを調製した。

\section{2 測 定}

加水分解生成物及び生成物の加熱処理物は粉末 X 線 回折 ( $\mathrm{CuK} \alpha$, Ni-filter, Geigerflex-Rad $1 \mathrm{~B}$, 理学電機) により，相の同定を行った。単斜晶及び正方晶の割合は， Garvie ${ }^{13)}$ ，Baily ら ${ }^{14)}$ の方法を用いて求めたが，本実 験で得られる $\mathrm{ZrO}_{2}$ は生成段階では極めて微細であるた め正方晶と立方晶の判別は困難である。したがって，特 に詳しく記述しないかぎり正方晶と立方晶を区別せず立 方晶と記すことにする．格子定数の測定には内部標準と して Si を添加し， $2 \theta=80^{\circ} \sim 120^{\circ}$ の回折ピークを用い た。

生成粒子の形態は，生成物中の共存イオンを洗浄によ り取り除いた後，蒸留水で希釈，分散させ，銅製の試料 メッシュに取り，乾燥して透過型電子顕微鏡（TEM， JEM-200 CX, 日本電子) を用いて観察した.

$\mathrm{Ca}$ 共沈物の $150^{\circ} \mathrm{C}$ 熟成物については，化学分析によ り $\mathrm{ZrO}_{2}$ 中の $\mathrm{CaO}$ 固溶量を求めた。固溶体を再び分解 するため, $2 \mathrm{~N} \mathrm{HCl}$ とともにゲル化物を熟成処理同様圧 力容器にて $200^{\circ} \mathrm{C}, 48$ 時間加熱処理し, 沪過した後, キレート滴定により沪液中の $\mathrm{CaO}$ 量を定量した。

\section{3. 結果と考察}

\section{1 $\mathrm{ZrO}_{2}-\mathrm{Y}_{2} \mathrm{O}_{3}$ 系}

共沈水酸化物は調製したよきには糊状である。熟成処 理によってもこの状態に見掛け上変化はないが, 糊状物 を水洗した後，Y共沈物からの生成物の場合には，大 量の水を加え，かくはんしながら塩酸を徐々に加えてい くと透明性の高いゾル $(\mathrm{pH} 2$ 2 3) となる. その後, 単 斜晶 $\mathrm{ZrO}_{2}$ ゾルの場合 ${ }^{12)}$ と同様に陰イオン交換樹脂にて pH 5〜6に調整した.

生成物の TEM 写真の一例を図 1 (a) に示す. $97^{\circ} \mathrm{C}$, 5 日間熟成処理物から得られたゾルは一辺の長さが 60 $120 \AA ̊$ の立方体状の極めて微細な粒子からなっている。 このゾルを乾燥することによって透明性の高いゲル状物 が得られる。

$\mathrm{Y}$ 共沈物の $97^{\circ} \mathrm{C} ， 5$ 日間熟成物の粉末 $\mathrm{X}$ 線回折を図 2 に示す。生成物はいずれも結晶性が低く, $\mathrm{Y}_{2} \mathrm{O}_{3}$ 添加 量 $0 \mathrm{~mol} \%$ では非晶質であるが, $\mathrm{Y}_{2} \mathrm{O}_{3}$ 添加量の増大に
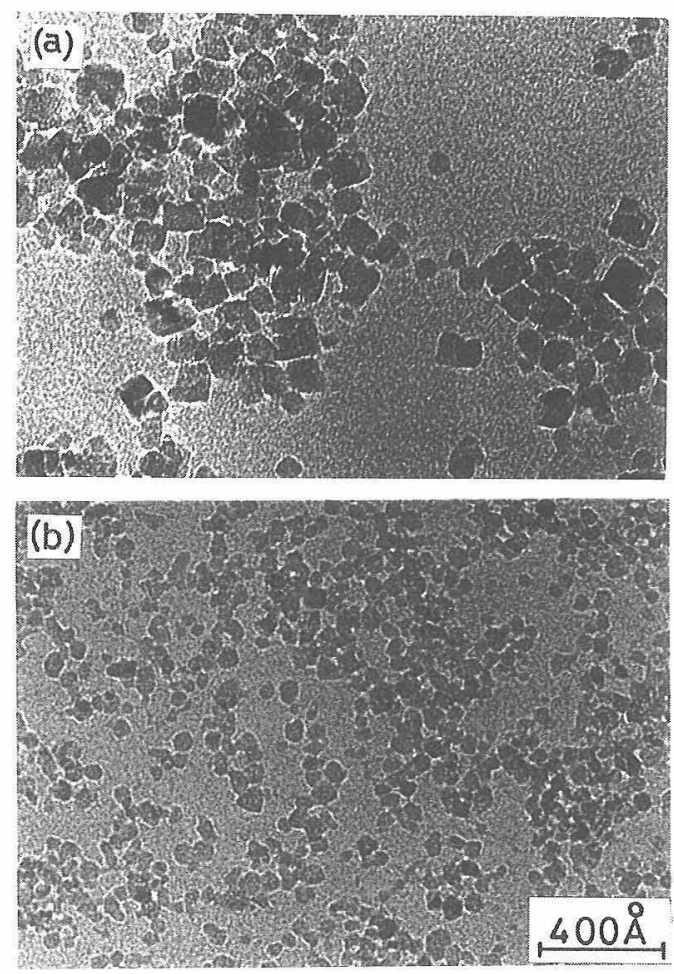

Fig. 1. TEM photographs of cubic $\mathrm{ZrO}_{2}$ solid solutions obtained by aging (a) coprecipitated hydroxide corresponding to $10 \mathrm{~mol} \% \quad \mathrm{Y}_{2} \mathrm{O}_{3}-\mathrm{ZrO}_{2}$ composition at $97^{\circ} \mathrm{C}$ for $5 \mathrm{~d}$ and (b) coprecipitated hydroxide corresponding to $10 \mathrm{~mol} \% \mathrm{CaO}-\mathrm{ZrO}_{2}$ composition at $150^{\circ} \mathrm{C}$ for $3 \mathrm{~d}$.

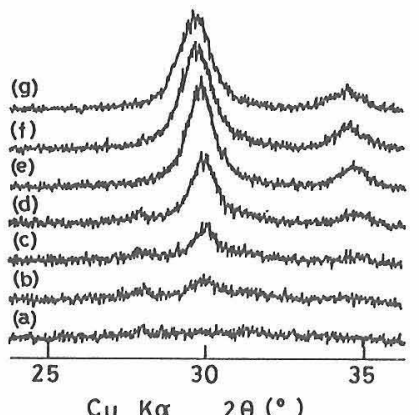

Fig. 2. X-ray diffraction patterns of coprecipitated hydroxide in $\mathrm{Y}_{2} \mathrm{O}_{3}-\mathrm{ZrO}_{2}$ system after aging at $97^{\circ} \mathrm{C}$ for $5 \mathrm{~d}$. Amounts of the additive (corresponding to $\mathrm{Y}_{2} \mathrm{O}_{3}$ mol\%) are (a) 0, (b) 2, (c) 3, (d) 5, (e) 10, (f) 20, (g) 30 , respectively.

伴って，立方晶の回折強度及び見掛けの結晶子径が増大 し, $20 \mathrm{~mol} \%$ では $D_{111}=95 \AA$ となった。しかしながら， それ以上の $\mathrm{Y}_{2} \mathrm{O}_{3}$ 添加量では回折強度, 見掛けの結晶子 径共に減少する傾向がみられた。また，10 $\mathrm{mol} \%$ 以上 において，各回折線の低角へのシフトが見られた。これ らの生成物を $1200^{\circ} \mathrm{C}, 1$ 時間加熱処理すると, 図 3 に 示すように, $0 \mathrm{~mol} \%$ では単斜晶のみとなるが, $\mathrm{Y}_{2} \mathrm{O}_{3}$ 


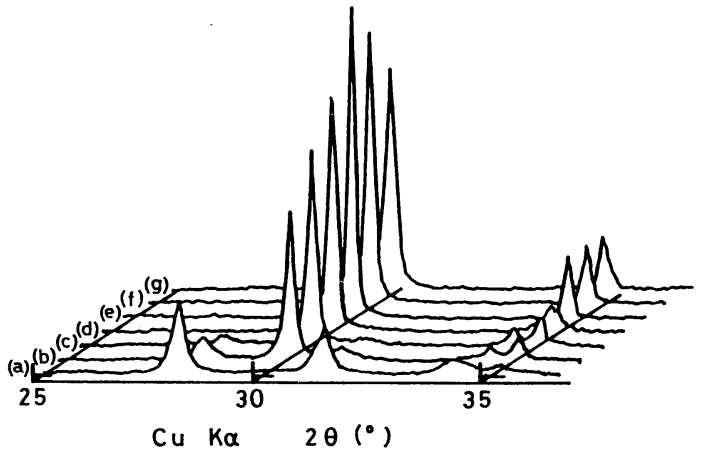

Fig. 3. X-ray diffraction patterns of the products same as in Fig. 2 after heating at $1200^{\circ} \mathrm{C}$ for $1 \mathrm{~h}$.

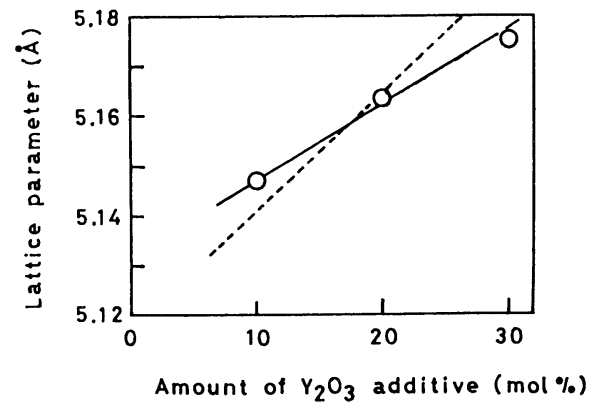

Fig. 4. Change of lattice parameter of cubic $\mathrm{ZrO}_{2}$ solid solution with amount of $\mathrm{Y}_{2} \mathrm{O}_{3}$ additive.

$\bigcirc$ : present work, …: after C. Pascual et al ${ }^{15)}$.

添加量 $2 \mathrm{~mol} \%$ で $31 \%$ 単斜晶 $+69 \%$ 正方晶, $3 \mathrm{~mol} \%$ で $16 \%$ 単斜晶 $+84 \%$ 正方晶と, $\mathrm{Y}_{2} \mathrm{O}_{3}$ 添加量の増加と ともに正方晶の割合が増え， $5 \mathrm{~mol} \%$ では正方晶十立方 晶, $10 \mathrm{~mol} \%$ 以上では立方晶のみとなった。 以上の実 験結果は $\mathrm{Zr}$ と $\mathrm{Y}$ の共沈水酸化物の $97^{\circ} \mathrm{C}$ という水の沸 点以下の温度での長時間の熟成によって $\mathrm{ZrO}_{2}-\mathrm{Y}_{2} \mathrm{O}_{3}$ 固 溶体が生成すること, $\mathrm{Y}_{2} \mathrm{O}_{3} 5 \mathrm{~mol} \%$ 以上の添加量で正 方晶 $\mathrm{ZrO}_{2}$ を安定化するのに十分な $\mathrm{Y}_{2} \mathrm{O}_{3}$ が固溶するこ とを明らかに示している.

$1200^{\circ} \mathrm{C}$ で加熱処理された $\mathrm{Y}_{2} \mathrm{O}_{3}$ 添加量 $10 \mathrm{~mol} \%$ 以上 の立方晶 $\mathrm{ZrO}_{2}$ の格子定数の変化を Pascual ら ${ }^{15)}$ のデー 夕と比較して図 4 に示す.ここで, $\mathrm{Y}_{2} \mathrm{O}_{3}$ の添加量に対 する格子定数の変化は Pascual らの結果と比較すると 少ない。横軸の $\mathrm{Y}_{2} \mathrm{O}_{3}$ 添加量は共沈水酸化物としての添 加量を示し, その後共沈物の水洗及び熟成は $\mathrm{Y}(\mathrm{OH})_{3}$ の飽和溶液で行っているので, $\mathrm{ZrO}_{2}$ の結晶化過程で $\mathrm{Y}_{2} \mathrm{O}_{3}$ の増加又は減少が起こるものと考えられる.

\section{3. $2 \mathrm{ZrO}_{2}-\mathrm{CaO}$ 系}

$\mathrm{Ca}$ 共沈物の場合でも, 図 5 に示すように, $97^{\circ} \mathrm{C}$ での 熟成により極めて結晶性の低い立方晶 $\mathrm{ZrO}_{2}$ が生成す る. しかしながら，この生成物は Y 共沈物の場合と異 なり酸に極めて弱く, pH 2 以下では溶解するため, 塩 酸添加によって解こうしてゾルとすることは困難であ

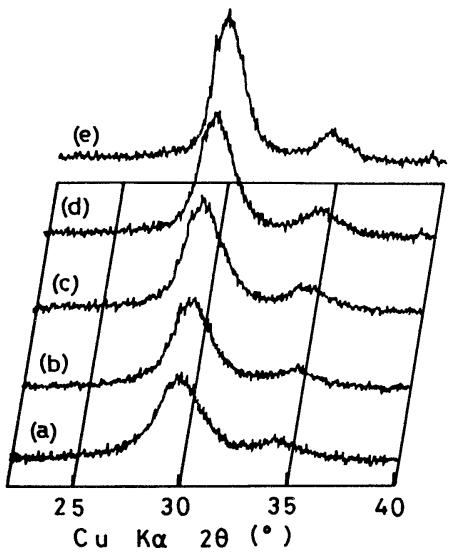

Fig.5. X-ray diffraction patterns of coprecipitated hydroxide corresponding to the composition of $10 \mathrm{~mol} \%$ $\mathrm{CaO}-\mathrm{ZrO}_{2}$ after aging.

(a) at $97^{\circ} \mathrm{C}$ for $3 \mathrm{~d},\left(\right.$ b) at $120^{\circ} \mathrm{C}$ for $0.5 \mathrm{~d}$,

(c) at $120^{\circ} \mathrm{C}$ for $3 \mathrm{~d},(\mathrm{~d})$ at $150^{\circ} \mathrm{C}$ for $3 \mathrm{~d}$,

(e) at $200^{\circ} \mathrm{C}$ for $3 \mathrm{~d}$

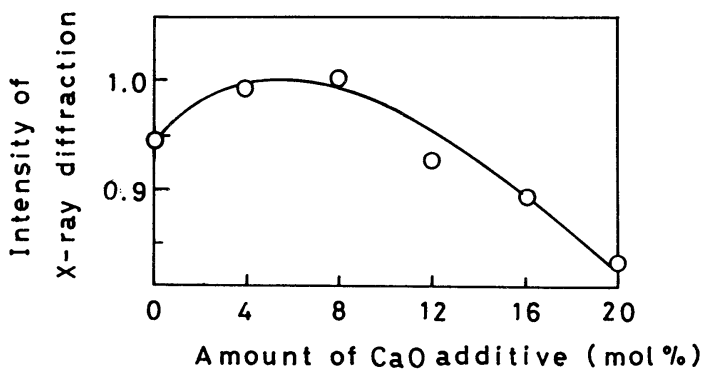

Fig. 6. Change of the intensity of X-ray diffraction for 111 reflection of cubic $\mathrm{ZrO}_{2}$ with amount of $\mathrm{CaO}$ additive $(\operatorname{mol} \%)$.

る. 熟成温度の上昇とともに生成 $\mathrm{ZrO}_{2}$ 相の結晶性は高 くなり，耐酸性も増す. $\mathrm{CaO} 10 \mathrm{~mol} \%$ 添加試料での $150^{\circ} \mathrm{C} ， 3$ 日間熟成によって生成した立方晶 $\mathrm{ZrO}_{2}$ の結 晶子径 $D_{111}$ は $40 \AA$ であるが, 本実験での酸処理では $\mathrm{Ca}$ 分の溶出が認められなかったので, 以後の実験には この条件を用い, ゾル調製における塩酸添加量は最小限 とし， $\mathrm{pH}$ を 2 3 調節した. 図 1 (b) はこの $\mathrm{ZrO}_{2}$ 粒 子の $\mathrm{TEM}$ 写真である. 粒径は $97^{\circ} \mathrm{C}$ 熟成により生成し た $\mathrm{Y}_{2} \mathrm{O}_{3}$ 固溶体の約半分の $30 \sim 60 \AA$ で，形状は丸みを 帯びている.

$\mathrm{CaO}$ 添加量 0 20 mol\% の本実験範囲のいずれにお いても立方晶 $\mathrm{ZrO}_{2}$ が生成した。図 6 に正方晶又は立方 晶 $\mathrm{ZrO}_{2}$ の回折 (111 反射) 強度 (内部標準 $\mathrm{Si} 111$ 反射) の $\mathrm{Ca}$ 添加量に対する変化を示す.ここで, $\mathrm{Y}_{2} \mathrm{O}_{3}$ 添加 と異なって $\mathrm{CaO}$ 添加量 $0 \mathrm{~mol} \%$ でも立方晶 $\mathrm{ZrO}_{2}$ が生 成する.これは添加量 $0 \mathrm{~mol} \%$ が $\mathrm{Y}_{2} \mathrm{O}_{3}, \mathrm{CaO}$ とも共沈 物における添加量を示し, 水洗及び熟成ではそれぞれ $\mathrm{Y}(\mathrm{OH})_{3}, \mathrm{Ca}(\mathrm{OH})_{2}$ の飽和溶液を使用しているためで, 
その濃度及び $\mathrm{pH}$ は $\mathrm{Ca}(\mathrm{OH})_{2}$ の方が極めて高いことに よると考えられる. $\mathrm{CaO}$ 添加量の増加とともに立方晶 $\mathrm{ZrO}_{2}$ の回折強度は増加し, $8 \mathrm{~mol} \%$ で最大となった。 以 後回折強度は低下の傾向が認められた。

これらの生成物を $1200{ }^{\circ} \mathrm{C}$ で加熱処理したものの格子 定数を図 7 に示す.このなかで $\mathrm{CaO}$ 添加量 $0 \mathrm{~mol} \%$ の 場合のみ単斜晶が $3.2 \%$ 含まれ，他は立方晶である. $\mathrm{CaO}$ 添加量の增加とともに格子定数は $a=5.132$

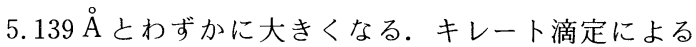
$\mathrm{CaO}$ 含有量の分析結果を表 1 に示す. $\mathrm{CaO}$ 含有量は $15.3 \mathrm{~mol} \% \sim 18.8 \mathrm{~mol} \%$ まで $\mathrm{Ca}(\mathrm{OH})_{2}$ 添加量の増加と ともに増えるが, $\mathrm{CaO}$ 添加量の変化に比べて, 固溶体 中の $\mathrm{Ca}$ 含有量の変化は非常に小さいことが注目され る.これは, 溶液中の $\mathrm{Ca}(\mathrm{OH})_{2}$ 濃度が高く, 溶解析出 機構が関与すること, $\mathrm{Ca}(\mathrm{OH})_{2}$ の溶解度の温度係数が 負であり, 室温で飽和状態であった $\mathrm{Ca}(\mathrm{OH})_{2}$ が熟成温 度では析出し, 反応物として供給されるためと考えられ る. 本実験の結果は Hellmann ${ }^{16)} ら の \mathrm{CaO}$ 固溶量と格 子定数の関係とほぼ一致しているが, 加水分解処理条件, ゾル調製条件等が生成 $\mathrm{Zr}_{2}$ 超微結晶に及ぼす影響につ いての検討が更に必要と考えられる.

\section{3 水溶液中での正方又は立方晶 $\mathrm{ZrO}_{2}$ 超微粒子の 生成}

通常, 室温付近の低温では $\mathrm{ZrO}_{2}$ は $\mathrm{MgO}, \mathrm{CaO}$, $\mathrm{Y}_{2} \mathrm{O}_{3}$ いずれ之の固溶系においても単斜晶が安定である とされている.しかしながら, 超微粒子状態では主とし

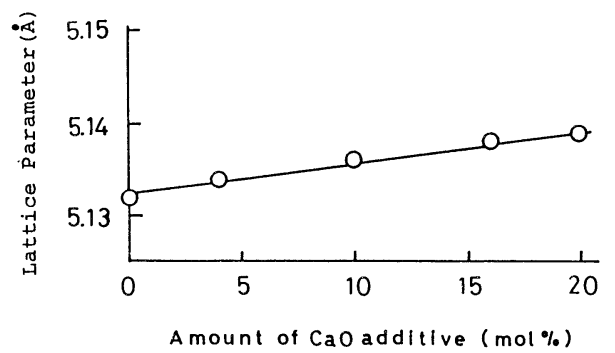

Fig. 7. Change of the lattice parameter for cubic $\mathrm{ZrO}_{2}$ solid solution heated at $1200^{\circ} \mathrm{C}$ for $1 \mathrm{~h}$ with the amount of $\mathrm{CaO}$ additive $(\mathrm{mol} \%)$.

Table 1. Chemical and X-ray diffraction analyses of cubic $\mathrm{ZrO}_{2}-\mathrm{CaO}$ solid solutions obtained by aging at $150^{\circ} \mathrm{C}$ for $3 \mathrm{~d}$.

\begin{tabular}{|c|c|c|c|}
\hline & \multicolumn{2}{|c|}{ Amount of additive } & \multirow{2}{*}{$\begin{array}{l}(\mathrm{Ca} 0) \\
16 \mathrm{~mol} \%\end{array}$} \\
\hline & 0 mol\% & $4 \mathrm{~mol} \%$ & \\
\hline \multicolumn{4}{|l|}{$\mathrm{CaO}$ content in $\mathrm{ZrO}_{2}$} \\
\hline Chemical analysis & $15.3 \mathrm{~mol} \%$ & $16.4 \mathrm{~mol} \%$ & $18.8 \mathrm{~mol} \%$ \\
\hline Calc. from lattice parameter* & 15.6 & 16.5 & 18.2 \\
\hline \multicolumn{4}{|l|}{$\mathrm{ZrO}_{2}$ phase } \\
\hline Aged at $150^{\circ} \mathrm{C}$ & Cubic & Cubic & Cubic \\
\hline fired at $1200^{\circ} \mathrm{C}$ & $\begin{array}{l}\text { Cubic }+ \\
\text { Monoclinic }\end{array}$ & Cubic & Cubic \\
\hline
\end{tabular}

て単斜晶と正方晶との表面自由エネルギーの差により， また，Y，Caなどいわゆる安定化剂の固溶によって， 正方晶 $\mathrm{ZrO}_{2}$ が室温で存在することが知られている，村 瀬らは単斜晶 $\mathrm{ZrO}_{2}$ 超微粒子を用いて, 粒成長が抑制さ れた状態では $500^{\circ} \mathrm{C}$ 以上の加熱処理で, $\mathrm{Y}\left(\mathrm{NO}_{3}\right)_{3}$ と接 触した状態では $400{ }^{\circ} \mathrm{C}$ 以下の極めて低い温度で, 単斜 晶から正方晶への転移が起こることを見いだし ${ }^{17), 18)}$, 後 者について, 表面自由エネルギーと安定化剂の固溶によ る化学自由エネルギー変化の相乗作用によるものと説明 した.

水溶液反応では, $250^{\circ} \mathrm{C}$ 以下の熟成処理により, 固溶 成分の有無に必ずしも関係なく正方晶又は立方晶 $\mathrm{ZrO}_{2}$ が生成することが知られている ${ }^{7), 8}$. むしろ $200^{\circ} \mathrm{C}$ 以下 での低温熟成処理では, 固溶成分としての Ca が結晶構 造に取り込まれないとの報告もある(1).

本実験においては, 安定化剤の添加量の少ない試料に おいて, $1200^{\circ} \mathrm{C} て ゙ の$ 加熱処理によって, 粒成長に伴っ て単斜晶が出現した. 安定化剤の添加量の多い試料につ いては, 加熱処理温度の上昇に伴って結晶性は高くなる が単斜晶への転移は認められなかった。 また, 化学分析 (表 1) 並びに $1200^{\circ} \mathrm{C}$ 加熱処理物の格子定数測定 (図 4, 7）により $\mathrm{Ca}$ 及び $\mathrm{Y}$ の固溶が確認された。このように, 従来の報告よりも低い熟成処理温度でも十分な時間をか ければ, 安定化㓮が固溶した正方晶又は立方晶 $\mathrm{ZrO}_{2}$ が ほぼ平衡状態として生成することが明らかである.

\section{4 ゾルゲル法による安定化立方 $\mathrm{ZrO}_{2}$ 薄膜の調製}

本実験で得られた $10 \mathrm{~mol} \% \mathrm{Y}_{2} \mathrm{O}_{3}$ 及び $\mathrm{CaO}$ 立方晶 $\mathrm{ZrO}_{2}$ 超微粒子を用いて, 既報 ${ }^{21}$ と同じ方法によりゾル ゲル薄膜を調製した。PVAを含んだゲル膜は高い透光 性を示す. 昇温 $\left(2^{\circ} \mathrm{C} / \mathrm{min}\right)$ によりまず PVA が炭化し, 膜は不透明になるが, $500^{\circ} \mathrm{C}$ までに炭素が燃焼して再び 膜は透明になる. 更に, 約 $900^{\circ} \mathrm{C}$ から粒成長の進行に つれて不透明になるが, $1200^{\circ} \mathrm{C}$ から再び透光性が増す

(図 8 ). 膜厚は乾燥ゲルのとき $\mathrm{Y}_{2} \mathrm{O}_{3}$ 固溶体では 40 $\mu \mathrm{m}, \mathrm{CaO}$ 固溶体では $20 \mu \mathrm{m}$ であったものが $1350^{\circ} \mathrm{C}$, 30 分間焼成後それぞれ $25,13 \mu \mathrm{m}$ となった. また $\mathrm{Y}_{2} \mathrm{O}_{3}$ 固溶体では約 $1 \sim 2 \mu \mathrm{m}, \mathrm{CaO}$ 固溶体では約 $2 \sim 4 \mu \mathrm{m}$ の 粒子がち密な組織を構成しているのが分かる(図 9 ).

これらの膜は単斜晶 $\mathrm{ZrO}_{2}$ フィルムの場合 ${ }^{12)}$ に比較し て, 平面性が悪くなる.これは, 単斜 $\mathrm{ZrO}_{2}$ 超微結晶が 長方形状であり, 粒子相互が絡み合ってフィルムの形状 を保つのに対し, 本実験における立方 $\mathrm{ZrO}_{2}$ 超微結晶は 立方体状又は球状に近い形状であるのに起因している. また, 単斜晶 $\mathrm{ZrO}_{2}$ 超微結晶ゾルに $\mathrm{YCl}_{3}$ を添加して調 製したゾルゲル薄膜か配向性を示した $\left.{ }^{19}\right)$ の対して, 本 方法では薄膜の配向性は認められなかった。

しかしながら, 立方晶 $\mathrm{ZrO}_{2}$ は $\mathrm{O}^{2-}$ イオン導電体とし 固相反応によって固溶体を生成させるよりも, 本方法の 
(a)

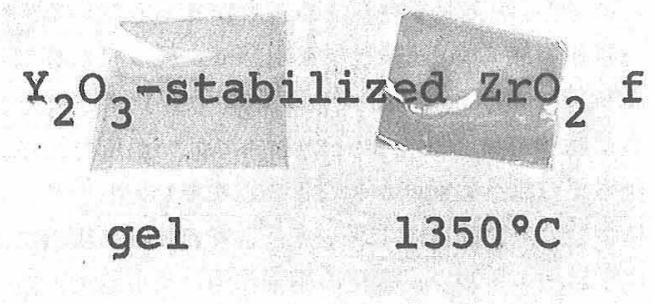

(b)

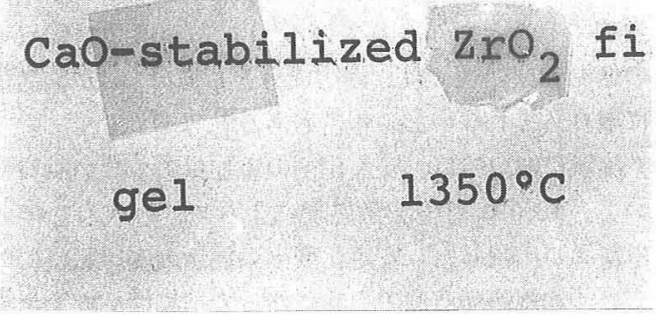

Fig. 8. Stabilized cubic $\mathrm{ZrO}_{2}$ films prepared by sol-gel process using (a) $\mathrm{ZrO}_{2}-\mathrm{Y}_{2} \mathrm{O}_{3}$ solid solution sol, and (b) $\mathrm{ZrO}_{2}-\mathrm{CaO}$ solid solution sol, respectively.

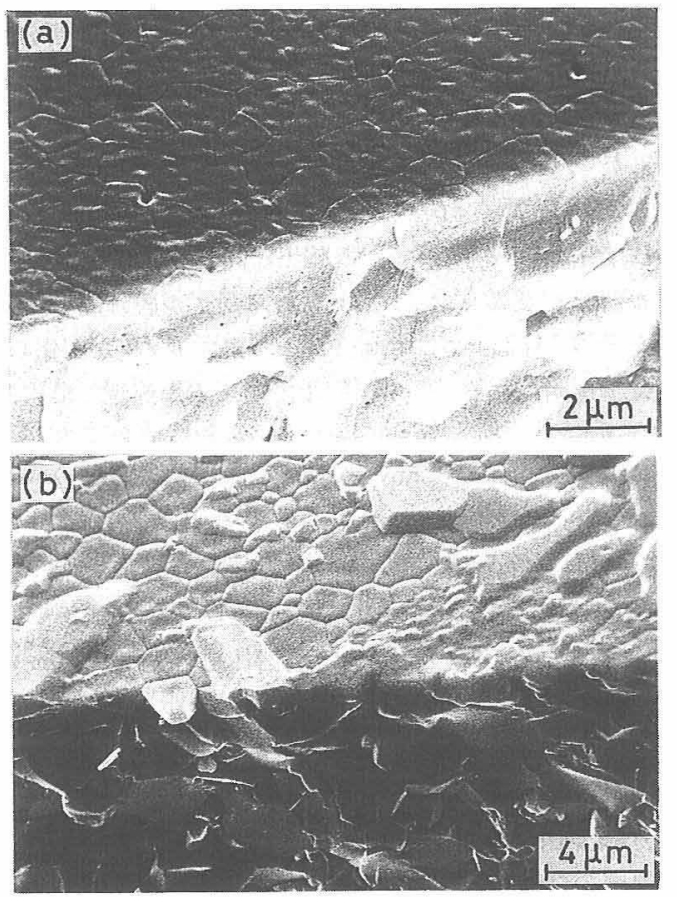

Fig. 9. SEM photographs of the sol-gel films for (a) $\mathrm{ZrO}_{2}-\mathrm{Y}_{2} \mathrm{O}_{3}$ solid solution and (b) $\mathrm{ZrO}_{2}-\mathrm{CaO}$ solid solution fired at $1350^{\circ} \mathrm{C}$ for $30 \mathrm{~min}$.

て注目されており，高濃度の安定化剂が薄膜の各微小部 分で均一に固溶していることが望ましい，したがって， ゾルに固溶成分を添加し，ゾルゲル薄膜を調製した後の
ような，低温長時間の熟成処理によって生成した固溶体 微結晶の応用は極めて有用であると考えられる。

\section{4. 総括}

$\mathrm{Zr}$ と $\mathrm{Y}$ 又は $\mathrm{Ca}$ との共沈水酸化物を低温長時間熟成 処理して次の結果を得た。

(1) $\mathrm{ZrO}_{2}-\mathrm{Y}_{2} \mathrm{O}_{3}$ 系では, $97^{\circ} \mathrm{C}$ という極めて低い温 度で立方晶 $\mathrm{ZrO}_{2}$ 超微粒子が生成した。

（2）この超微粒子は，一辺の長さが $60 \sim 120 \AA$ の 立方体の形状を持ち, 分散性の高いゾルとなる。

（3）この系では，10 30 mol\% の固溶体が容易に 生成する。

(4) $\mathrm{ZrO}_{2}-\mathrm{CaO}$ 系においても， $97^{\circ} \mathrm{C}$ 長時間の熟成 によって立方晶 $\mathrm{ZrO}_{2}$ が生成するが酸に極めて弱く, 部 分的な溶解なしにゾルに解膠することはできなかった。

（5） $150^{\circ} \mathrm{C} ， 3$ 日間熟成することにより $\mathrm{Y}$ 共沈物の $97^{\circ} \mathrm{C}$ 熟成物よりも更に微細な粒子の立方晶 $\mathrm{ZrO}_{2}$ が得 られた。

(6)この $\mathrm{CaO}$ 固溶量は $15.3 \sim 18.8 \mathrm{~mol} \%$ であり, 原料水酸化物への $\mathrm{CaO}$ 添加量による変化はわずかで あった。

（7）本実験で得られた $\mathrm{ZrO}_{2}$ 超微粒子ゾルを用い $\tau$, 膜厚 13〜25 $\mu \mathrm{m}$ の透明な立方晶 $\mathrm{ZrO}_{2}$ 薄膜が調製さ れた。

\section{文 献}

1) A. Clearfield, Inorg. Chem., 3, 64-48 (1964).

2）村瀬嘉夫, 松本秀夫, 加藤悦朗, 日化, 1972, 2329-36(1972).

3) H. Saricimen, Powder Tech., 27, 23-28 (1980).

4）村瀬嘉夫, 加藤悦朗, 窯協, 84, 478-81 (1976).

5）月舘隆明, 津久間孝次, セラミックス, 17, 816-22 (1982).

6）村瀬嘉夫, 加藤悦朗, 平野正典, 墨協, 91, 561-64 (1983).

7) T. Mitsuhashi, M. Ichihara and U. Tatsuke, J. Am. Ceram. Soc., 57, 97-101 (1974).

8) H. Nishizawa, N. Yamasaki, K. Matsuoka and H. Mitsushio, J. Am. Ceram. Soc., 65, 343-46 (1982).

9) E. Tani, M. Yoshimura and S. Sōmiya, J. Am. Ceram. Soc., 66, 11-14 (1983).

10) A. R. Burkin, H. Saricimen and B. C. H. Steele, Trans. J. Brit. Ceram. Soc, , 79, 105-08 (1980).

11) H. Nishizawa, T. Tani and K. Matsuoka, J. Mater. Sci., 19, 2921-26 (1984).

12）江副正信，村瀬嘉夫，大門啓志，加藤悦朗，蒸協，94, 823-26 (1986).

13) R. C. Garvie and P.S. Nicholson, J. Am. Ceram. Soc., 55, 303 (1972).

14) J. E. Bailey, D. Lewis, Z. M. Librant and L. J. Porter, Trans, and J. Brit. Ceram. Soc, , 71, 25-32 (1972).

15) C. Pascual and P. Duran, J. Am. Ceram. Soc., 66, 23-27 (1983).

16) J.R. Hellmann and V.S. Stubican, J.Am. Ceram. Soc., 66, 260-64 (1983).

17) Y. Murase, E. Kato and K. Daimon, J. Am. Ceram. Soc. , 69, 83-87 (1986).

18）村瀬嘉夫，西川文茂，大門啓志，加藤悦朗，窯協，95, 423-28 (1987).

19) E. Kato, M. Ezoe, K. Daimon, The 3 rd International Conference and Technology of Zirconia, in Print. 